\title{
Serological markers of hepatitis B in patients with alcoholic liver disease: a multi-centre survey
}

\author{
WS HISLOP,* EAC FOLLETT, $\dagger$ IAD BOUCHIER,* RNM MACSWEEN $\ddagger$
}

\begin{abstract}
From the *Department of Medicine, Ninewells Hospital and Medical School, Dundee, the $\dagger$ Regional Virus Laboratory, Ruchill Hospital, Glasgow, and the $\ddagger$ University Department of Pathology, Western Infirmary, Glasgow
\end{abstract}

SUMMARY In a study of 195 patients derived from five centres in northern Britain and with histologically confirmed alcoholic liver disease we have found an increased prevalence of serological markers of hepatitis B. This increased prevalence was found in each of the five centres; the overall frequency ranged from $11 \%$ sero-positivity in fatty liver, $12 \%$ in alcoholic hepatitis and $27 \%$ in cirrhosis.

In two previous studies from Glasgow, a significantly increased prevalence of hepatitis B virus (HBV) antibody was found in patients with alcoholic liver disease, in particular in patients with alcoholic cirrhosis. ${ }^{12}$ The reason(s) for this could not be established, and there was a possibility, albeit remote, that it might represent a local phenomenon peculiar to alcoholic liver disease in the west of Scotland. In the present study the prevalence of HBV markers has been examined in a series of 195 patients entering a survey of alcoholic liver disease in four cities in Scotland-Aberdeen, Dundee, Edinburgh and Glasgow, and one in the north of EnglandNewcastle-upon-Tyne.

\section{Patients and methods}

The patients, 151 men (mean age $51 \mathrm{yr}$, range 27-76) and 44 women (mean age $49 \mathrm{yr}$, range 23-72), all caucasian, were admitted to one of eight medical units co-operating in a survey of alcoholic liver disease funded by the Scottish Home and Health Department. A serum sample was obtained from each patient (in some more than one sample was examined) and was referred to the Regional Virus Laboratory, Ruchill Hospital, Glasgow for the HBV marker studies. The serum samples were coded and the results reported without prior knowledge of the histological diagnosis.

Each patient had a percutaneous needle biopsy of liver performed, and a histological diagnosis of alcohol-induced liver disease was established using routine staining methods. A distinction was made between active and inactive cirrhosis; in the former

Accepted for publication 23 March 1981 features of alcoholic hepatitis ${ }^{3}$ were additionally present, whereas in the latter these were absent and evidence of liver cell necrosis was minimal.

Tests for hepatitis B surface antigen (HBsAg), antibody to HBsAg (anti-HBs) and antibody to HB core antigen (anti-HBc) were carried out by standard radioimmunoassay methods (Ausria, II, Ausab and Corab-Abbott Laboratories) and reported as positive or negative compared with standard controls. Positive results for anti-HBs and anti-HBc were confirmed on repeated testing, and anti-HBs was only accepted as positive if the count was greater than five times the negative control mean, thus excluding any borderline results.

\section{Results}

The results obtained for each centre are summarised in Table 1. The prevalence of $\mathrm{HBV}$ markers ranges from $10 \%$ of alcoholic liver disease patients in Glasgow to $23 \%$ in Dundee, with an overall mean of $18 \%$. Of the 36 patients in whom HBV markers were found 24 had both anti-HBs and anti-HBc, 2 had anti-HBc and HBsAg, 5 had anti-HBs alone, and 5 had anti-HBc alone.

The distribution of HBV markers according to the histological diagnosis is summarised in Table 2. This shows that the overall prevalence of HBV markers increases from $11 \%$ in patients with fatty liver to $30 \%$ in patients with inactive cirrhosis.

\section{Discussion}

In the present study we have found an increased prevalence of HBV markers in a series of patients with histologically documented alcoholic liver 
Table 1 Distribution of patients and markers of $\mathrm{HBV}$ infection in different centres. Percentages of total numbers per centre are shown in brackets

\begin{tabular}{|c|c|c|c|c|c|c|}
\hline & \multirow[t]{2}{*}{ Total No } & \multicolumn{5}{|c|}{ Hepatitis $B$ virus markers } \\
\hline & & $H B s A g$ & anti-HBc alone & anti-HBs alone & $\begin{array}{l}\text { Both anti-HBc and anti- } \\
\text { HBs }\end{array}$ & $\begin{array}{l}\text { Total with at least } \\
\text { one marker }\end{array}$ \\
\hline $\begin{array}{l}\text { Aberdeen } \\
\text { Dundee } \\
\text { Edinburgh } \\
\text { Glasgow } \\
\text { Newcastle }\end{array}$ & $\begin{array}{l}21-6 \mathrm{~F}^{*} \\
40-10 \mathrm{~F} \\
50-15 \mathrm{~F} \\
42-9 \mathrm{~F} \\
42-4 \mathrm{~F}\end{array}$ & $\begin{array}{l}0 \\
1 \dagger \\
1 \dagger \\
0 \\
-\end{array}$ & $\begin{array}{l}- \\
3 \\
1 \\
1\end{array}$ & $\begin{array}{l}-1 \\
\frac{1}{2}\end{array}$ & $\begin{array}{l}3 \\
7 \\
4 \\
3 \\
7\end{array}$ & $\begin{array}{r}3(14) \\
9(23)-2 \mathrm{~F} \\
10(20)-1 \mathrm{~F} \\
4(10)-1 \mathrm{~F} \\
10(24)-1 \mathrm{~F}\end{array}$ \\
\hline
\end{tabular}

${ }^{*} \mathrm{~F}=$ female.

†These were also positive for anti-HBc.

Table 2 Distribution of markers of $H B V$ infection according to the histological diagnosis of alcoholic liver disease. Percentages are shown in brackets

\begin{tabular}{|c|c|c|c|c|c|c|}
\hline & \multirow[t]{2}{*}{ Total No } & \multicolumn{5}{|c|}{ Hepatitis $B$ virus markers } \\
\hline & & $H B s A g$ & ant $i-H B c$ alone & anti-HBs alone & $\begin{array}{l}\text { Both anti-HBc and anti- } \\
H B s\end{array}$ & $\begin{array}{l}\text { Total with at least } \\
\text { one marker }\end{array}$ \\
\hline $\begin{array}{l}\text { Fatty liver } \\
\text { Alcoholic }\end{array}$ & $62-10 F^{*}$ & - & 1 & 2 & 4 & $7(11)-1 \mathrm{~F}$ \\
\hline $\begin{array}{l}\text { hepatitis } \\
\text { Alcoholic } \\
\text { cirrhosis }\end{array}$ & $43-14 \mathrm{~F}$ & - & 1 & 一 & 4 & $5(12)-1 F$ \\
\hline $\begin{array}{l}\text { active } \\
\text { inactive }\end{array}$ & $\begin{array}{ll}80-19 & F \\
10-1 F\end{array}$ & $2 \dagger$ & $\begin{array}{l}2 \\
1\end{array}$ & 3 & $\begin{array}{r}14 \\
2\end{array}$ & $\begin{array}{l}21(26)-3 \mathrm{~F} \\
3(30)\end{array}$ \\
\hline Totals & $195-44 F$ & $2(1)$ & $5(3)$ & $5(3)$ & $24(12)$ & $36(18)-5 \mathrm{~F}$ \\
\hline
\end{tabular}

$* F=$ female.

tThese were both positive for anti-HBc.

disease, derived from five different centres in northern Britain. This confirms the earlier observations made by Mills and his colleagues in Glasgow. ${ }^{2}$ In previous studies using radioimmunoassay techniques identical to or of equal sensitivity to those used in the present study, the frequency of HB surface antigenaemia in the general population in the west and east of Scotland was 1 in $841^{4}$ and 1 in $771^{5}$ respectively, and this compares with 2 of 195 in our series of alcoholic-liver disease patients; the frequency of anti-HBs in the west and east of Scotland was $2.2 \%$ and $2.9 \%$ respectively, findings which compare with an overall $15 \%$ positive rate in the present study. It is thus apparent that in five centres in northern Britain there is good evidence of an association between alcoholic liver disease and HBV infection.

Buffet and his colleagues (personal communication) in a study of 27 French patients with alcoholic liver disease found anti-HBs and anti-HBc in $10(37 \%)$ and $13(47 \%)$ patients respectively. In a recently reported prospective study from the alcohol treatment unit of the Brockton VA Medical Centre in Boston, Chopra and his colleagues ${ }^{8}$ found an overall prevalence of $\mathrm{HBV}$ infection of $25.5 \%$ in a series of 90 consecutive patients admitted to the unit. The sera of these patients were screened for HBsAg $(1 \cdot 1 \%$ positive), anti-HBs $(24 \%)$ and anti-HBc $(19 \%)$, but the authors do not indicate whether there was any clinical evidence of liver disease in the patients, nor did they study a control group. These reports however, provide further evidence of a possible association between alcoholic liver disease and $\mathrm{HBV}$ infection.

Mills and his colleagues ${ }^{12}$ were not able to offer an explanation for the increased prevalence of $\mathrm{HBV}$ infection in alcoholic liver disease. Factors such as social class, age and previous history of possible exposure by blood transfusion, tattooing etc were excluded by these workers. We are similarly not able to offer an explanation for the present findings. The increased risk of $\mathrm{HBV}$ infection among male homosexuals is now well documented. ${ }^{9-11}$ We have no record of the sexual orientation of the patients currently studied, but we do not think that this is the likely explanation for our findings.

In the patients who were sero-positive for HBV markers there was no clinical indication as to when they had acquired this infection. Of the 36 seropositive patients 24 were found to have both anti$\mathrm{HBs}$ and anti-HBc, an antibody profile indicating recovery from the hepatitis episode with elimination 
of the virus and the development of an immune state. In 7 patients anti-HBc but no anti-HBs was demonstrated, and in 2 of these HBsAg was also found. The failure of these 7 patients to produce anti-HBs suggests a possible carrier state and they will be the subject of continued follow-up.

Our results also show an increased prevalence of HBV infection in fatty liver, the mildest form of alcoholic liver disease, but the highest incidence occurred in patients with cirrhosis. It is noteworthy that a $26 \%$ prevalence of HBV markers has been found in patients with active alcoholic cirrhosis. In the biopsies from these patients features of alcoholic hepatitis were also present, and thus the assumption must be that the cirrhosis was alcoholinduced. In contrast, in the 10 patients with inactive cirrhosis, and in whom HBV markers were found in $3(30 \%)$, stigmata of alcoholic liver disease were absent, and the possibility cannot be excluded that, in these patients, the cirrhosis occurred with alcoholism but was of a different aetiology. We have no evidence, however, in any of the patients studied, that the HBV infection contributed to the liver injury, although the possibility cannot at present be excluded.

The findings reported in this paper suggest that there is an increased susceptibility to HBV infection in patients with alcoholic liver disease and these patients may represent an important source of $\mathrm{HBV}$ infection in the community.

This study was supported by Scottish Home and Health Department Grants, K/MRS/50/C14 to Professor IAD Bouchier and K/MRS/50/161 to Professor RNM MacSween and Dr HM Dick.

It is a pleasure to thank our clinical colleagues who entered patients in this study: Drs PW Brunt
(Aberdeen), MA Eastwood and NDC Finlayson (Edinburgh), JG Allan, G Watkinson and RI Russell (Glasgow) and OFW James (Newcastle).

\section{References}

${ }^{1}$ Mills PR, Pennington TH, Kay P, MacSween RNM, Watkinson G. Hepatitis Bs antibody in alcoholic cirrhosis. J Clin Pathol 1979;32:778-82.

${ }^{2}$ Mills PR, Follett EAC, Urquhart GED, Clements G, Watkinson G, MacSween RNM. Hepatitis B and other viral antibodies in alcoholic cirrhosis. $\mathrm{Br}$ Med $J$ 1981; 282:437-8.

${ }^{3}$ MacSween RNM. Alcoholic liver disease. In: Anthony PP, Woolf $\mathrm{N}$, eds. Recent Advances in Histopathology. Vol. 10 London: Churchill Livingstone, 1978:193-212.

${ }^{4}$ Barr A, Dow BC, MacVarish I. HBsAg detection-results of a comparative large scale testing of blood donations. Med Lab Sci 1979;36:109-14.

${ }^{5}$ Hopkins R, Ross S, Jordon P, Watt AD. Improved economics of HBsAg screening with commercial radioimmunoassay reagents. J Clin Pathol 1980;33:1923.

- Follett EAC, Barr A, Crawford RJ, Mitchell R. Viral hepatitis markers in blood donors and patients with a history of jaundice. Lancet 1980; : $246-9$.

${ }^{7}$ Burrell CJ, Tonkin RW, Proudfoot E, et al. Prevalence of antibody to hepatitis B surface antigen among staff in an Edinburgh hospital. J Hyg (Lond) 1977;78:57-68.

${ }^{8}$ Chopra RA, Tupper JC, Ahn CS, Bayog R, Koff RS. Hepatitis $B$ markers in an alcohol treatment unit. Gastroenterology 1980;79 (proceedings) 11c.

${ }^{9}$ Heathcote J, Sherlock S. Spread of acute type-B hepatitis in London. Lancet 1973 ; i :1468-70.

${ }^{10}$ Coleman JC, Evans RA, Thornton A, Zuckerman AJ. Homosexual hepatitis. J Infect 1979;1:61-6.

11 Ellis WR, Coleman JC Fluker JL, et al. Liver disease among homosexual males. Lancet 1979; :903-4.

Requests for reprints to: Professor RNM MacSween, Department of Pathology, Western Infirmary, Glasgow G11 6NT, Scotland. 